\title{
Adverse childhood experiences are associated with the risk of lung cancer: a prospective cohort study
}

\author{
David W Brown*1,2, Robert F Anda' ${ }^{1}$, Vincent J Felitti³, Valerie J Edwards ${ }^{1}$, Ann Marie Malarcher ${ }^{1}$, Janet B Croft ${ }^{1}$ and \\ Wayne H Giles ${ }^{1}$
}

\section{Correction}

After the publication of this work [1], we became aware that Table 5 (Table 1) incorrectly duplicated the informa- tion in Table 6. We have corrected this error and have inserted the correct Table 5 (Table 1) below.

Table 5: Frequency, age-adjusted risk and risk ratio of the occurrence of lung cancer, identified by death records, between baseline and 31 December 2005 by number of categories of adverse childhood experiences (ACEs) and smoking status among 16,901 adults

\begin{tabular}{|c|c|c|c|c|c|c|}
\hline & \multirow[b]{2}{*}{$\mathbf{N}$} & \multirow[b]{2}{*}{$\begin{array}{l}\text { Person- } \\
\text { Time (yrs) }\end{array}$} & \multirow[b]{2}{*}{ Deaths | } & \multirow[b]{2}{*}{$\begin{array}{l}\text { Mortality } \\
\text { Rate*** }\end{array}$} & \multicolumn{2}{|c|}{ Relative risk of lung cancer* } \\
\hline & & & & & $\begin{array}{l}\text { Model A } \\
\text { RR (95\% Cl) }\end{array}$ & $\begin{array}{l}\text { Model B } \\
\text { RR }(95 \% \text { Cl) }\end{array}$ \\
\hline \multicolumn{7}{|l|}{ Categories of ACEs, No. } \\
\hline 0 & 6124 & 44,592 & $44 \mid$ & 26.0 & 1.00 (referent) & 1.00 (referent) \\
\hline 1 & $4411 \mid$ & 31,709 & $22 \mid$ & 19.3 & $0.80(0.48-1.34)$ & $0.74(0.44,1.23)$ \\
\hline 2 & 2681 & 19,045 & $22 \mid$ & 66.4 & $1.48(0.89-2.49)$ & $1.30(0.77,2.18)$ \\
\hline 3 & 1599 & 11,056 & $11 \mid$ & 51.3 & $1.52(0.78-2.96)$ & $1.17(0.59,2.29)$ \\
\hline 4 or 5 & $1637 \mid$ & 11,259 & $8 \mid$ & 30.0 & $1.32(0.61-2.83)$ & $1.00(0.46,2.16)$ \\
\hline \multirow[t]{2}{*}{6,7, or 8} & 449 & 2901 & $4 \mid$ & 62.7 & $3.55(1.25-10.09)$ & $2.34(0.81,6.75)$ \\
\hline & & & & & $P$ for trend $=0.025$ & $P$ for trend $=0.251$ \\
\hline \multicolumn{7}{|l|}{ Smoking status } \\
\hline Never & $8589 \mid$ & 61,713 & $11 \mid$ & 8.5 & & 1.00 (referent) \\
\hline Former & $6879 \mid$ & 49,379 & $73 \mid$ & 58.0 & & $5.92(3.10-11.30)$ \\
\hline Current, $<20 \mathrm{cig} / \mathrm{d}$ & 870 & 5748 & $10 \mid$ & 129.7 & & $12.43(5.23-29.57)$ \\
\hline Current, $>20 \mathrm{cig} / \mathrm{d}$ & 563 & 3722 & $17 \mid$ & 357.1 & & $28.15(12.77-62.08)$ \\
\hline Total & $16,901 \mid$ & 120,562 & $111 \mid$ & 31.1 & & \\
\hline
\end{tabular}

ACEs, adverse childhood experiences $\mathrm{RR}$, risk ratio $\mathrm{Cl}$, confidence interval

* Underlying cause of death from lung cancer defined by ICD-9 code 162 for deaths between 1995-1998; ICD-10 code C34 for deaths between 1999 and 2005.

** Rate (per 100,000 person-years) age-standardized to the 2000 Census population for California. Model $A$ adjusted for age, sex, race/ethnicity, education, married, financial problems

Model $B$ adjusted for age, sex, race/ethnicity, education, married, financial problems, smoking status, parental smoking history. In addition to the RR estimates for ACE score, we show the RR estimates for smoking status from the regression model.

\footnotetext{
* Correspondence: dwbrown.6@gmail.com

1 Centers for Disease Control and Prevention, Atlanta, Georgia, USA

Full list of author information is available at the end of the article
} 
We regret any inconvenience that this oversight may have caused.

\section{Author Details}

'Centers for Disease Control and Prevention, Atlanta, Georgia, USA,

${ }^{2}$ Netherlands Institute for Health Sciences, Erasmus University Medical Center, Rotterdam, the Netherlands and ${ }^{3}$ Southern California Permanente Group

(Kaiser Permanente), San Diego, California, USA

Received: 25 May 2010 Accepted: 4 June 2010

Published: 4 June 2010

\section{References}

1. Brown DW, Anda RF, Felitti VJ, Edwards VJ, Malarcher AM, Croft JB, Giles WH: Adverse childhood experiences are associated with the risk of lung cancer: a prospective cohort study. BMC Public Health 2010, 10:20.

\section{Pre-publication history}

The pre-publication history for this paper can be accessed here: http://www.biomedcentral.com/1471-2458/10/311/prepub

doi: 10.1186/1471-2458-10-311

Cite this article as: Brown et al., Adverse childhood experiences are associated with the risk of lung cancer: a prospective cohort study BMC Public Health 2010, 10:31

Submit your next manuscript to BioMed Centra and take full advantage of:

- Convenient online submission

- Thorough peer review

- No space constraints or color figure charges

- Immediate publication on acceptance

- Inclusion in PubMed, CAS, Scopus and Google Scholar

- Research which is freely available for redistribution 